\title{
CARCASS CHARACTERISTICS AND MEAT QUALITY IN CULL EWES AT DIFFERENT AGES
}

\section{CARACTERÍSTICAS DA CARCACA E QUALIDADE DA CARNE EM OVELHAS DE DESCARTE DE DIFERENTES IDADES}

\author{
Geisa Isilda Ferreira Esteves ${ }^{1 *}$ \\ Vanessa Peripolli2 \\ Adriana Morato Menezes ${ }^{3}$ \\ Helder Louvandini ${ }^{4}$ \\ Alessandra Ferreira Silva ${ }^{3}$ \\ Caio Cesar Cardoso ${ }^{3}$ \\ Concepta McManus ${ }^{3}$ \\ 1 Instituto Federal Catarinense, Rio do Sul, SC, Brazil. \\ 2Instituto Federal Catarinense, Araquari, SC, Brazil. \\ ${ }^{3}$ Universidade de Brasília, Brasília, DF, Brazil. \\ ${ }^{4}$ Universidade de São Paulo, CENA, Piracicaba, SP, Brazil \\ *Corresponding author - vanessa.peripolli@hotmail.com
}

\begin{abstract}
The objective of this trial was to evaluate carcass quality in 74 Santa Ines hair ewes aged 6 to 48 months. Slaughter occurred after fasting and electroshock, followed by dissection of the jugular veins and carotid arteries. Hot carcass weight, hot carcass yield, carcass length, skin thickness, shoulder, neck, loin, belly, rib and leg weights and percentages, leg length, and girth were measured. The rib eye area, color (by CIELAB system), shear force, and cooking loss were also measured. The data were analyzed using SAS procedures for analysis of variance, regressions, correlations, and principal components. Hot carcass weight was $15.75 \mathrm{~kg}$ and yield was $43.65 \%$. Younger animals had higher leg yield while yields of loin and shoulder increased as age increased. The meat was darker in older animals. As age increased, both the quantity of commercial cuts decreased and the loss of quality traits, such as color, cooking loss, and shear force, increased; therefore, slaughter should be performed before 30 months of age.
\end{abstract}

Keywords: carcass yield; sheep; slaughter weight; tenderness.

\section{Resumo}

O objetivo deste trabalho foi avaliar a qualidade da carcaça em 74 ovelhas Santa Inês deslanadas com idades entre 6 a 48 meses. O abate ocorreu após jejum e eletrochoque, seguido de dissecção das veias jugulares e artérias carótidas. As avaliações realizadas foram peso de carcaça quente, rendimento de carcaça quente, comprimento de carcaça, espessura da pele, pesos e percentagens de ombro, pescoço, lombo, fralda, costelas e pernil e comprimento e perímetro do pernil. A área de olho de lombo, a cor usando o sistema CIELAB, a força de cisalhamento e a perda por cocção também foram avaliados. Os dados foram submetidos às análises de variância, regressões, correlações e de componentes principais utilizando o pacote estatístico SAS. O peso de carcaça quente foi $15,75 \mathrm{~kg}$ e o rendimento de carcaça foi 
de 43,65\%. Os animais mais jovens apresentaram maior rendimento de pernil enquanto os rendimentos de lombo e ombro aumentaram com a idade. A carne foi mais escura em animais mais velhos. Com o aumento da idade, ocorreu redução na quantidade dos cortes comerciais e aumento das perdas de características de qualidade como cor, perda por cocção e força de cisalhamento; portanto, o abate deve ser realizado antes de 30 meses de idade.

Palavras-chave: maciez; ovinos; peso de abate; rendimento de carcaça.

Received on: February 5th, 2015.

Accepted on: November 24th, 2017.

\section{Introduction}

Efficient meat production, that is, of consistent quality and value, is necessary for the sheep meat industry to remain competitive ${ }^{(1)}$. Consumers have shown growing interest in sheep and goats meat, probably because of their organoleptic quality, nutritional value, and palatability ${ }^{(2)}$. One of the primary objectives of the red meat industry has been an attempt to deliver consistently high quality meat to consumers. Eating quality has long been recognized as a determinant for repeat purchasing ${ }^{(3)}$.

There is low availability of sheep products in Brazil due to insufficient production and a trade volume that does not allow the industrialization of the production system. This seriously affects the abattoirs working with small ruminants ${ }^{(4)}$. It is estimated that $50 \%$ of sheep meat consumed in Brazil is imported from New Zealand, Australia, and Uruguay. New Zealand only produces $6 \%$ of the world's sheep meat but over $90 \%$ of the sheep meat produced there is exported ${ }^{(5)}$.

Santa Ines breed represents nowadays the largest hair sheep population in Brazil, showing countrywide distribution $^{(6)}$. Consequently, it is common to use this breed in crosses with exotic breeds specialized in meat production ${ }^{(7)}$. Most crossbreeding studies in Brazil have been carried out using Santa Ines dam and Texel sire; however, the majority of studies evaluated only two or three genetic groups ${ }^{(8)}$.

A high percentage of income from sheep production comes from the sale of cull animals for meat ${ }^{(9,10)}$. Therefore, the objective of this study was to evaluate carcass quality in Santa Ines ewes of different ages.

\section{Material and Methods}

The study was approved by the Ethics Committee for Animal Use (CEUA) of the University of Brasilia. The experiment was conducted at the Center for Sheep Management of the Água Limpa Farm of University of Brasilia, Brazil. Seventy-four female Santa Ines sheep, aged between 6 and 48 months and weighing between 25 and $58 \mathrm{~kg}$, were used. The animals were weighed before fasting (WBF) and body condition score (BCS) was assessed. The animals were weighed again (WAF) and slaughtered after a 16hour water and solid food fast. Hot carcass weight (HCW) was used to obtain hot carcass yield (HCY) by the formula (HCY = HCW / WAF x 100). External carcass length (CL) was also measured.

After 24 hours of cooling in a cold room at $4{ }^{\circ} \mathrm{C}$, the left side of the carcass was sectioned into six regions called retail cuts ${ }^{(11)}$. The neck, shoulder, rib, belly, loin, and leg were weighed individually and leg length 
and circumference were measured. The neck refers to the seven cervical vertebrae, making an oblique cut between the seventh cervical and first thoracic vertebrae; the shoulder comprises the region whose anatomical basis is the scapula, humerus, ulna, radius and the carpus; the belly corresponds to the anatomical region of the abdominal wall; the rib corresponds to two thirds of the loin; its base is the bone corresponding to half of the sternum cut sagittally taking in approximately $2 / 3$ of the eight ventral ribs and ventral third of the remaining five; the loin includes six lumbar vertebrae; the leg was sectioned at the joint of the last lumbar and first sacral and the tarsal-metatarsal joint, based on the bone of the ilium, pubis, the ischium, femur, tibia, and tarsus.

The outline of a cross-section of the Longissimus dorsi muscle between the 12th and 13th ribs was traced and the rib eye area (REA) was determined on a grid with $1 \mathrm{~cm}^{2}$ squares.

Cook loss was calculated using a gas oven preheated to $170{ }^{\circ} \mathrm{C}$. Samples of approximately $1 \mathrm{~cm}^{3}$ of raw meat were weighed, placed in trays and reweighed. A thermocouple was placed in the geometric center of the sample. The samples were left in the oven until the thermocouple reached the temperature of $40{ }^{\circ} \mathrm{C}$. The sample was then turned. They were kept in the oven until the internal temperature of the center of the sample reached $70^{\circ} \mathrm{C}$. The trays were removed from the oven and when cooled, they were weighed again to calculate the percentage of cook loss (CL).

Shear force (SF) was determined using the same samples used to determine moisture loss during cooking. The samples were cooled completely and stored in bags in the refrigerator for 24 hours. Three samples from each meat sample were cut with the aid of a stainless steel cutting cylinder. These were analyzed in the transverse direction of muscle fibers with the aid of Warner Bratzler shear force instrument $\left(\mathrm{kgf}^{-}\right.$ ${ }^{2}$ ) and averaged.

Meat color (CIELAB) was evaluated on Longissimus dorsi with the aid of a Minolta Chrome® colorimeter, calibrated to a standard white tile and $\mathrm{L}^{*}, \mathrm{a}^{*}$ and $\mathrm{b}^{*}$ were determined, where ( $\left.\mathrm{L}^{*}\right)$ is luminosity, $\left(\mathrm{a}^{*}\right)$ is the red color level and $\left(\mathrm{b}^{*}\right)$ the yellow color level. Four color evaluations were averaged for each sample.

Data were analyzed using the software Statistical Analysis System - SAS® (SAS Institute, Cary, North Carolina, v.9.3). Analysis of variance (PROC MIXED), correlation (PROC CORR) and principal components (PROC PRINCOMP) were carried out. Averages were compared (Duncan test) with a significance level of 5\%. Traits with high coefficients of variation were transformed to the logarithmic scale. A significant effect of age on carcass traits was studied using linear and quadratic regression (PROC REG) analyses.

\section{Results}

Age affected body condition score, skin thickness, and carcass length as well as color and tenderness traits (Table 1). Age had a quadratic effect on these traits, while body length increased, meat quality traits such as luminosity and tenderness decreased (Table 1).

Body condition score, carcass length, and skin thickness showed quadratic behavior in relation to age. In other words, variables increase up to a certain age, about 30 months, and then stabilized (Table 2). Age did not affect hot carcass weight, hot carcass yield, rib eye measurements and cook loss. Animals over 24 months had higher shear force values, demonstrating that the meat of these animals tends to be tougher. 
Most weight traits were not affected by the age at slaughter, while carcass composition tended to differ according to the age of the ewe at slaughter (Table 2). Rib weight and neck and rib yields had a quadratic regression. Loin and shoulder yields showed a linear behavior, i.e., variables continued to increase with increasing age, while leg yield decreased with increasing age.

Table 1. Effect of age on carcass traits, body condition score, skin thickness, rib traits, color traits, shear force and cook loss in Santa Ines cull ewes

\begin{tabular}{lcccc}
\hline Trait & Mean & CV & $\mathbf{R}^{2}$ & Equation \\
\hline Hot Carcass Weight $(\mathrm{kg})$ & 15.75 & 23.27 & 0.009 & Ns \\
Body Condition Score & 3.17 & 18.17 & 0.13 & BCS $=3.74-0.078 \times+0.001 \times 2$ \\
Hot Carcass Yield $(\%)$ & 43.65 & 13.53 & 0.27 & Ns \\
Skin Thickness $(\mathrm{cm})$ & 1.92 & 23.09 & 0.9 & $\mathrm{ST}=4.44-0.21 \times+0.002 \times 2$ \\
Carcass Length $(\mathrm{cm})$ & 69.17 & 7.45 & 0.8 & $\mathrm{CL}=52.19+1.64 \times-0.02 \times 2$ \\
Rib Eye Area $\left(\mathrm{cm}^{2}\right)$ & 11.76 & 20.47 & 0.19 & $\mathrm{Ns}$ \\
Rib Width A $(\mathrm{cm})$ & 5.53 & 9.06 & 0.05 & $\mathrm{Ns}$ \\
Rib Height B $(\mathrm{cm})$ & 2.81 & 19.89 & 0.22 & $\mathrm{Ns}$ \\
Fat $(\mathrm{mm})$ & 3.2 & 44.61 & 0.21 & $\mathrm{Ns}$ \\
L* & 36.36 & 7.65 & 0.51 & Luminosity $=40.88-0.48 \times+0.006 \times 2$ \\
a* & 16.74 & 7.57 & 0.18 & Red $=17.99-0.18 \times+0.0035 \times 2$ \\
b $^{*}$ & 7.34 & 17.44 & 0.41 & Yellow $=9.44-0.26 \times+0.004 \times 2$ \\
Shear Force $\left(\mathrm{kg} \mathrm{cm}^{-2}\right)$ & 2.09 & 31.6 & 0.50 & Shear $=1.05+0.10 \times-0.001 \times 2$ \\
Cook loss $(\%)$ & 17.33 & 25.75 & 0.10 & Ns \\
\hline
\end{tabular}

Fat; subcutaneous fat thickness; $L^{*}$; luminosity; $a^{*}$; red color level; $b^{*}$; yellow color level; CV; Coefficient of variation; $\mathrm{R}^{2}$ Coefficient of determination; $x$ : age in months.

Table 2. Effect of age on commercial cuts and measurements in Santa Ines cull ewes

\begin{tabular}{lcccc}
\hline Trait & Mean & CV & $\mathbf{R}^{2}$ & Equations \\
\hline Rib $(\mathrm{kg})$ & 1.83 & 23.99 & 0.56 & Rib $=2.55-0.07 \times+0.0009 \times 2$ \\
Belly $(\mathrm{kg})$ & 0.43 & 38.10 & 0.14 & $\mathrm{Ns}$ \\
Loin $(\mathrm{kg})$ & 0.67 & 24.43 & 0.51 & $\mathrm{Ns}$ \\
Neck $(\mathrm{kg})$ & 0.71 & 24.41 & 0.12 & $\mathrm{Ns}$ \\
Shoulder $(\mathrm{kg})$ & 1.43 & 19.70 & 0.31 & $\mathrm{Ns}$ \\
Leg $(\mathrm{kg})$ & 2.33 & 17.80 & 0.14 & $\mathrm{Ns}$ \\
Leg Diameter $(\mathrm{cm})$ & 36.8 & 7.59 & 0.10 & $\mathrm{Ns}$ \\
Leg Length $(\mathrm{cm})$ & 54.93 & 5.60 & 0.33 & $\mathrm{Ns}$ \\
\% Rib & 23.26 & 14.06 & 0.74 & \%Rib $=32.68-0.94 \times+0.01 \times 2$ \\
\% Belly & 5.44 & 26.28 & 0.09 & Ns \\
\% Loin & 8.74 & 15.15 & 0.75 & \%Loin $=6.02+0.20 \times$ \\
\% Neck & 8.97 & 18.25 & 0.07 & \%Neck $=10.11-0.17 \times+0.003 \times 2$ \\
\% Shoulder & 18.59 & 10.56 & 0.64 & \%Shoulder $=15.46+0.25 \times$ \\
\%Leg & 30.11 & 9.58 & 0.31 & \%Leg $=32.64-0.29 \times$ \\
\hline
\end{tabular}

CV: Coefficient of variation, $R^{2}$ : Coefficient of determination, $\times$ : age in months.

Correlations between the traits measured varied widely (Tables 3 and 4). The correlations were positive with high mean values between age and body weight (BW), carcass length (CL), loin and shoulder weight, leg length, shear force, and loin and shoulder yields.

Skin thickness had a high negative value with the weight, i.e., by increasing one the other decreases. The commercial cuts except the rib had a positive correlation with the shear force, though the correlations 
were low. The rib contains more fat, which causes the decrease in shear force, explaining the negative correlation value. Correlations with color traits, except the rib and leg, were negatively correlated to light, redness, and yellowness, i.e., the smaller the cut the darker the meat.

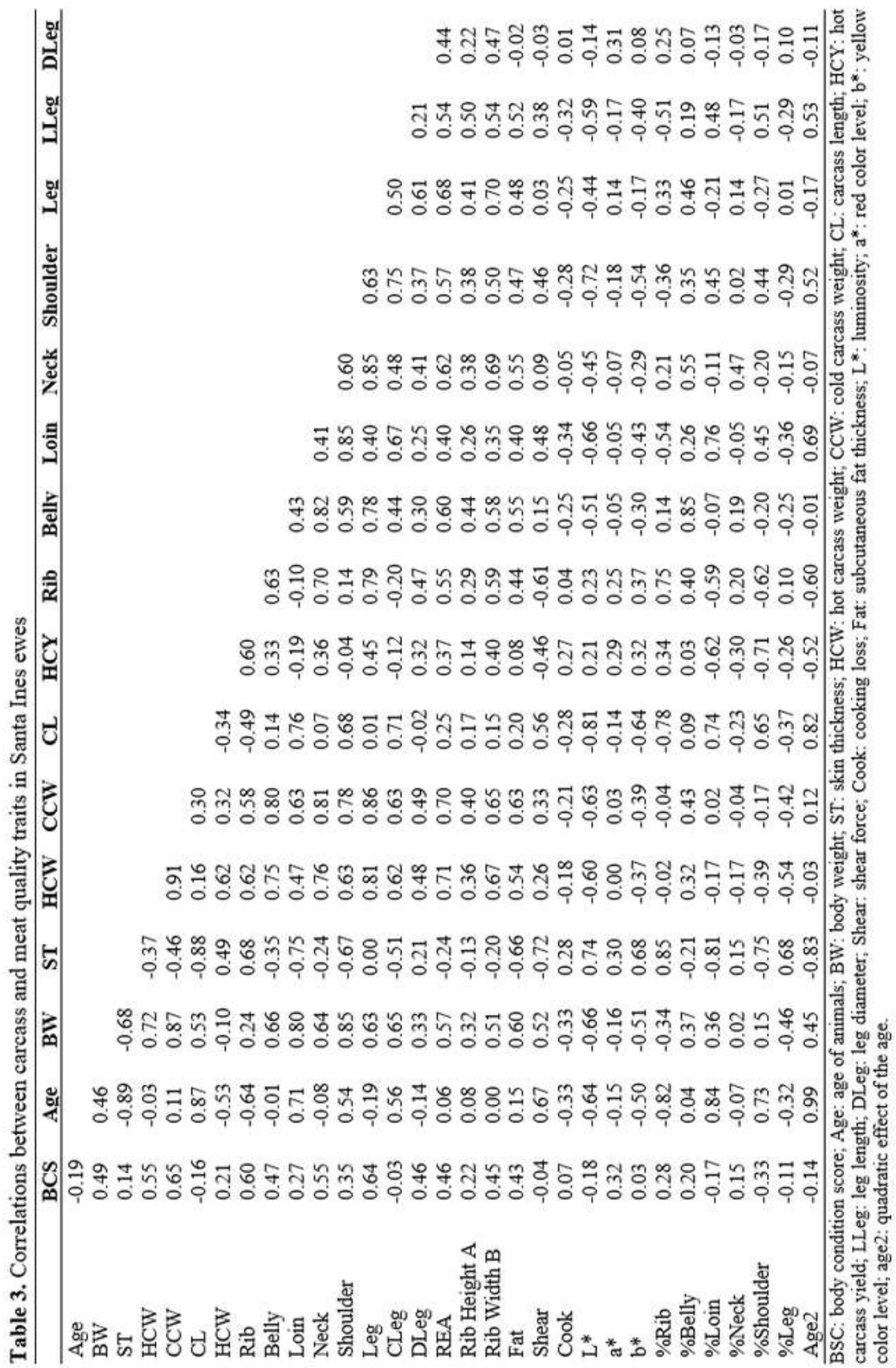




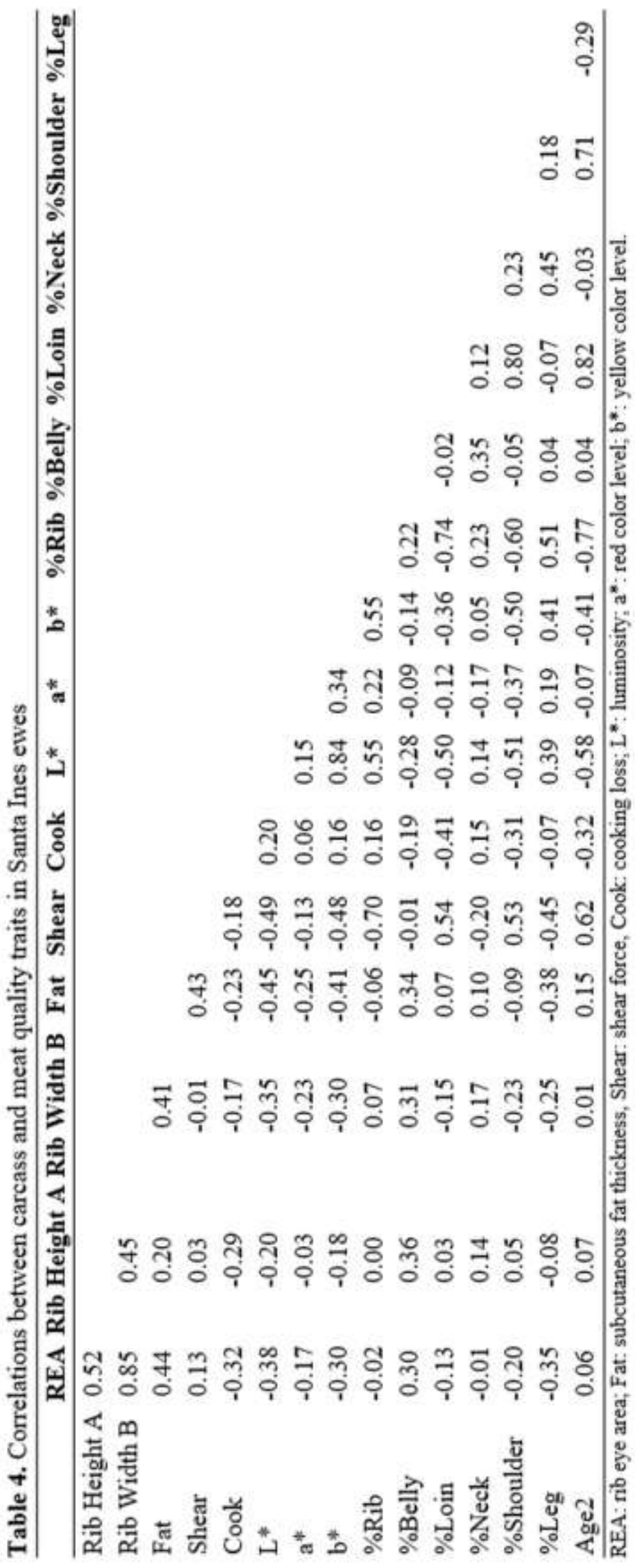


The first two principal components explained $63 \%$ of the variance among the characteristics (Fig. 1). The first eigenvector showed that carcass and cuts weight increased with age and, while the percentage of shoulder, belly, and loin increased, leg and rib decreased. This indicated a loss in the percentage of high value cuts with the increase of age. Rib eye area (REA), rib width A and rib height $\mathrm{B}$ of Longissimus dorsi are were higher if the animals are were slaughtered younger. The color was also lighter if animals were younger. The principal component analysis showed that increasing the age at slaughter causes a loss in both quantity of commercial cuts and characteristics such as color, cooking loss, and shear force. This means that meat from older animals had lower quality. The second eigenvector showed that the increase in leg weight, length, and diameter is was accompanied by a decreased in yield. The increase in shoulder, belly, loin, neck, and leg cuts produced a decrease of rib weight and also of leg, rib, and neck yields. The decrease in quality was accompanied by reduced cooking loss, brightness, and red and yellow content in meat.

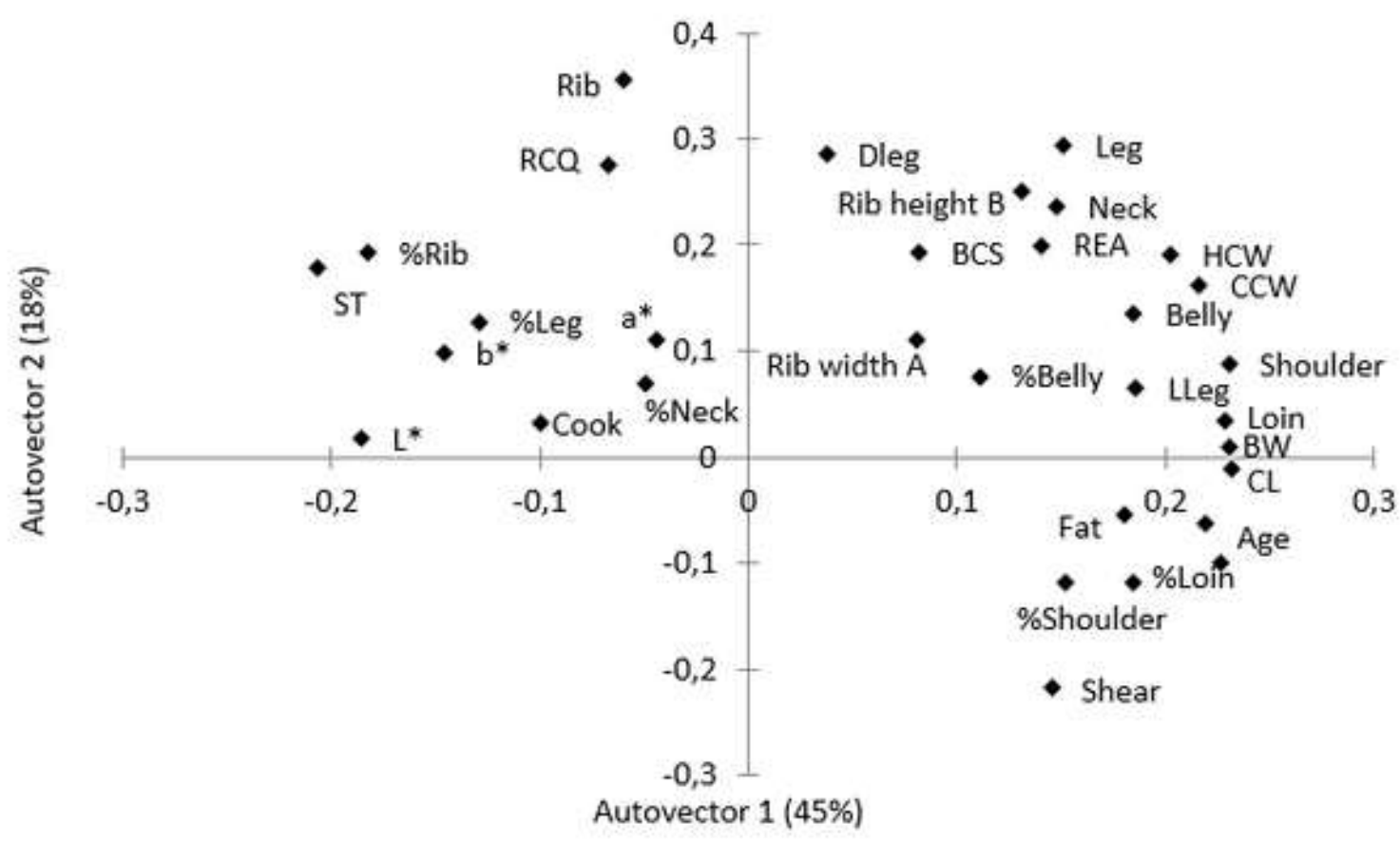

Figure 1. First two principal components for carcass traits in sheep females.

Abbreviations in tables 1-4

\section{Discussion}

In ruminant production for meat trade, it is important to try to determine the maximum age of slaughter for obtaining better carcass quality. This age would be the point at which the animal shows its best performance and where it is profitable for producers to keep this animal on the farm. In sheep it is common for dams to remain for a long period on the farm. This practice may not be profitable to the farmer, because the animal will be old and have poor carcass quality and thereby receive a low price compared to its purchase price. 
The literature does not work on the "ideal" age for slaughter, but Siqueira and Fernandes ${ }^{(12)}$ recommended around $16 \mathrm{~kg}$ as the ideal weight for carcass commercialization. The average hot carcass weight in this study was $15.75 \mathrm{~kg}$, which is considered an average weight for sheep in Brazil that is easily marketed ${ }^{(12)}$. In Iran, lambs with light carcass weight $(<13 \mathrm{~kg})$ are used for grilling, usually in an open market setting ${ }^{(13)}$. The heavier lambs are most often sold in retail outlets. Meat from light lambs is traditionally considered to be of better quality (more tender and less off-flavors) than meat from heavier animals ${ }^{(14)}$.

The loin $(0.67 \mathrm{~kg})$, shoulder $(1.43 \mathrm{~kg})$, leg $(2.33 \mathrm{~kg})$, and neck $(0.71 \mathrm{~kg})$ weights obtained in this study were higher than those reported by Santos Cabral et al. ${ }^{(15)}$. Santa Ines breed performs better when crossed with sire breeds with meat ability as Dorper, Texel and others. At the same maturity level, the growth performance, the age at slaughter, and the main carcass characteristics vary with the

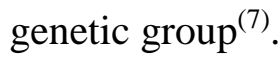

Ewes are one of the fundamental pillars of the sheep production system since they are used for herd replacement and meat production. Woolless sheep have high reproductive potential to be annual poliestric, presenting estrus, ovulation, and parturition, throughout the year ${ }^{(16)}$. For the producer to increase the profit margin of the activity, the use of management practices to achieve greater twin birth rates is necessary ${ }^{(17)}$. Much of the production cost is related to females maintenance.

The rib eye area in this experiment was lower $\left(11.72 \mathrm{~cm}^{2}\right)$, than the one observed by Souza et al. ${ }^{(7)}$, who studied whole crossbred Dorper x Santa Ines $\left(17 \mathrm{~cm}^{2}\right)$ and Dorper x Somalis $\left(13 \mathrm{~cm}^{2}\right)$ male lambs. The subcutaneous fat had higher mean $(3 \mathrm{~mm})$ than the one found by Santos Cabral et al. ${ }^{(15)}$ $(2 \mathrm{~mm})$. Generally, heavier older animals have low proportion of muscle and bone and high proportion of fat since they have less muscles ${ }^{(18)}$. Animals such as Santa Ines, which developed in hot climates, usually have poorly developed muscles and long legs to aid in heat loss ${ }^{(9)}$.

Color is an important visual trait denoting freshness and quality to consumers who prefer to purchase meat that is red rather than brown in color ${ }^{(19)}$. Variations from 30.03 to 49.47 for luminosity (L*), from 8.24 to 23.53 for red content $\left(\mathrm{a}^{*}\right)$ and from 3.38 to 11.10 for yellow content $\left(\mathrm{b}^{*}\right)$ can be found in sheep ${ }^{(20)}$. These data show that the values obtained in this study are within the normal range for color quality of sheep meat. The variations in brightness, redness, and yellowness occur depending on the age, weight, sex, pre- and post-slaughter handling, as well as the $\mathrm{pH}$ value postmortem. Color traits tend to worsen with age. The slaughter of sheep must occur before 30 months because, after this age, the worst values of luminosity $\left(\mathrm{L}^{*}\right)$, redness $\left(\mathrm{a}^{*}\right)$, and yellowness $\left(\mathrm{b}^{*}\right)$ are seen, leaving the meat darker and making this hard to market.

Kim et al. ${ }^{(21)}$ evaluated the shear force on 36 lambs aged four to eleven months. The average for younger animals was $3.4 \mathrm{~kg} \mathrm{~cm}^{-2}$ and for older animals was $3.1 \mathrm{~kg} \mathrm{~cm}^{-2}$. These values as well as the results of this experiment $\left(2.9 \mathrm{~kg} \mathrm{~cm}^{-2}\right)$ are considered soft meat. In both experiments the meat sample was stored for some period in the freezer. This storage period may have contributed to the proteins degradation leading to soft results in all samples ${ }^{(22)}$. However, with fat deposition this effect will be minimized because the fat is responsible for decreasing the shear force ${ }^{(18)}$. Samples of this experiment had a greater age variation compared to the samples evaluated by Kim et al. ${ }^{(21)}$.

Meat tenderness can be attributed to a two stage process: changes in the components of the meat tissue and weakening of myofibrils ${ }^{(23)}$. The first process is faster and produces changes in myofibrillar 
components; the second and slower one is where structural weakening of the intramuscular connective tissue occurs.

Correlations confirmed that increasing age increased body weight (BW), carcass length (CL), and shear force; this leads to less tender meat that is difficult to market without processing. Correlations between age and weight of the rib, belly, neck, and leg cuts were negative, i.e., as age increased the weights of the cuts decreased. This shows that with increasing age there are losses in commercial cuts and consequently loss in the producer income. For meat color and age, correlations were negative; therefore, in older animals the meat tends to be darker making it difficult to market.

Slaughter weight had high correlations with carcass weight, half-carcass weight and cold carcass weight as expected. This shows that with the increase of body weight, these characteristics tend to increase. Shear force had average correlation with live weight, confirming that older animals have tougher meat.

\section{Conclusions}

The highest weights of cuts, the highest yield, and improved quality traits such as color and texture were obtained in sheep slaughtered before 30 months of age.

\section{Acknowledgements}

Thanks are due to INCT - Pecuária (MCT, CNPq/FAPEMIG), FAPDF, and CAPES for scholarships and financial support.

\section{References}

1.Pethick DW, Warner RD, Banks RG. Genetic improvement of lamb - industry issues and the need for integrated research. Aust J Agric Res. [Internet], 2006 Jan [cited 2013 Dez 12]; 56: 591-592. Available from: http://www.publish.csiro.au/?act=view_file\&file_id=ARv57n6_PR.pdf

2. Montossi F, Font-i-Furnols M, Campo M, San Julián R, Brito G Sañudo C. Sustainable sheep production and consumer preference trends: Compatibilities, contradictions, and unresolved dilemmas. Meat Sci. 2013; 95(4): 772-789. Available from: http://dx.doi.org/10.1016/j.meatsci.2013.04.048

3. Grunert KG, Bredahl L, Brunso K. Consumer perception of meat quality and implications for product development in the meat sector-A review. Meat Sci. 2004; 66(20): 259-272. Available from: http://dx. doi.org/10.1016/S0309-1740(03)00130-X

4. Ximenes LJF , Cunha AM . Setor de peles e de couros de caprinos e de ovinos no nordeste [Internet]. Informe Rural ETENE-Banco do Nordeste; 2012 Mar 10 [cited 2014 Oct 24]. Available from: http://www.bnb.gov.br/documents/88765/89729/ire_ano6_n1.pdf/5d0b4811-9fdb-4136-9a6a-3a344c0d3079. Portuguese.

5. Conforte D, Jones N, Shadbolt NM, Lucock XS. ANZCO Foods Limited: Pursuing the Chinese Market. Int Food Agribus Man. [Internet], 2013 Jan [cited 2014 Jul 04]; 16(1): 87-114. Available from: 


\section{http://ageconsearch.umn.edu/bitstream/144675/2/20120061_Case.pdf}

6. McManus C, Hermuche P, Paiva SR, Moraes JCF, Melo CB, Mendes C. Geographical distribution of sheep breeds in Brazil and their relationship with climatic and environmental factors as risk classification for conservation. Braz J Sci Technol. [Internet], 2013 Jan [cited 2014 Nov 25]; 1:3, 2013.Available from:http://download.springer.com/static/pdf/199/art\%253A10.1186\%252F2196-288X-1-

3.pdf?auth66=1423152576_87dd64dd010b0ecfae5cccad33bdd37d\&ext=.pdf

7. Souza DA, Selaive-Villarroel AB, Pereira ES, Osório JCS, Teixeira, A. Growth performance, feed efficiency and carcass characteristics of lambs produced from Dorper sheep crossed with Santa Inês or Brazilian Somali sheep. Small Ruminant Res. 2013; 114(1): 51-55. Available from: http://dx. doi.org/10.1016/j.smallrumres.2013.06.006

8. McManus CM, Paiva SR, Araújo RO. Genetics and breeding of sheep in Brazil. 2010; 39(supl. esp.): 236246. Available from: http://dx.doi.org/10.1590/S1516-35982010001300026

9. McManus CM, Pinto BF, Martins RFS, Louvandini H, Paiva SR, Braccini Neto J, Paim TP. Selection objectives and criteria for sheep in Central Brazil. Rev Bras Zootec. 2011; 40(12): 2713-2720. Available from: http://dx.doi.org/10.1590/S1516-35982011001200014

10. Lôbo RNB, Pereira IDC, Facó O, McManus CM. Economic values for production traits of Morada Nova meat sheep in a pasture based production system in semi-arid Brazil. Small Ruminant Res. 2011; 96(2-3): 93100. Available from: http://dx.doi.org/10.1016/j.smallrumres.2011.01.009

11. Silva Sobrinho AG. Criação de ovinos. 2nd ed. Jaboticabal: FUNEP; 2001. 302p. Portuguese

12. Siqueira ER, Fernandes S. Pesos, rendimentos e perdas da carcaça de cordeiros Corriedale e mestiços Corriedale x Ile de France, terminados em confinamento. Ciência Rural. 1999; 29(1): 143-148. Available from: http://dx.doi.org/10.1590/S0103-84781999000100026

13. Alizadeh A, ZareShahneh A, Yousefi AR, HadinezhadOmran M, Campbell AW. Determining the effect of the fat-tail and carcass weight on meat fatty acid composition of Iranian lambs. Small Ruminant Res. 2013; 115(1-3): 34-39. Available from: http://dx.doi.org/10.1016/j.smallrumres.2013.06.004

14. Tejeda JF, Peña RE, Andrés AI. Effect of live weight and sex on physico-chemical and sensorial characteristics of Merino lamb meat. Meat Sci. 2008; 80(4): 1061-1067. Available from: http://dx.doi.org/10.1016/j.meatsci.2008.04.026

15. Santos Cabral Í, Azevêdo JAG, Almeida FM, Pereira LGR, Araújo GGL, Santos Cruz CL Oliveira GA. Performance and characteristics of carcass and non-carcass components of lambs fed peach-palm by-product. Trop Anim Health Prod. 2013; 45(8): 1737-1743. Available from: http://dx.doi.org/ 10.1007/s11250-0130424-1

16. Silva AVR, Santo EE, Pinto BF, Martins RFS, Louvandini H, Rohs SA, Rezende MLM, Murata LS, Queiroz EAP, Paiva SR, Garcia JAS, McManus C. Pesos econômicos para características de produção em ovinos no DF [Internet]. Caderno do CEAM (UnB); 2006 Sep 1 [cited 2014 Feb 20]; 25: 61-82. Available from: http://cmapspublic2.ihmc.us/rid=1188901709432_286482115_8459/Caderno\%2025.pdf. Portuguese.

17. Paim TP, Silva AF, Martins RFS, Borges BO, Lima PMT, Cardoso CC, Esteves GIF, Louvandini H, McManus C. Performance, survivability and carcass traits of crossbred lambs from five paternal breeds with local hair breed Santa Inês ewes. Small Ruminant Res. 2013; 112(1-3): 28-34. Available from: http://dx.doi.org/10.1016/j.smallrumres.2012.12.024

18. Sebsibe A, Casey NH, van Niekerk WA, Tegegne A, Coertze RJ. Growth performance and carcass characteristics of three Ethiopian goat breeds fed grainless diets varying in concentrate to roughage ratios. [Internet]. S Afr J Anim Sci. [Internet], 2007 Nov 10 [cited 2015 Jan 05]; 37(4): 221-232. Available from: 


\section{http://www.ajol.info/index.php/sajas/article/view/4094/11996}

19. King DA, Shackleford SD, Kuehn LA, Kemp CM, Rodriguez AB, Thallman RM, Wheeler TL. Contribution of genetic influences to animal to animal variation in myoglobin content and beef lean colour stability. J Anim Sci. 2010; 88(3): 1160-1167. Available from: http://dx.doi.org/10.2527/jas.2009-2544

20. Sañudo C, Enser ME, Campo MM, Nute GR, María G, Sierra I, Wood, J.D. Fatty acid composition andsensory characteristics of lamb carcasses from Britain and Spain. Meat Sci. 2000; 54(4): 339-346. Available from: http://dx.doi.org/10.1016/S0309-1740(99)00108-4

21. Kim YHB, Stuart A, Black C, Rosenvold K. Effect of lamb age and retail packaging types on the quality of long-term chilled lamb loins. Meat Sci. 2012; 90(4): 962-966. Available from: http://dx.doi.org/10.1016/j.meatsci.2011.11.040

22. Farouk MM, Beggan M, Hurst S, Stuart A, Dobbie PM, Bekhit AED. Meat quality attributes of chilled venison and beef. J Food Quality. 2007; 30(6): 1023-1039. Available from: http://dx.doi.org/ 10.1111/j.17454557.2007.00175.x

23. Warris PD. Meat Science: An introductory text. 1st ed. New York: CABI Publishing; 2000. 309p. 